\title{
Liberalism According to Štefan Launer or on an Ethno-Eman- cipation Theory
}

\author{
Marcela Gbúrová ${ }^{1}$ \\ Department of Political Science, UPJŠ Faculty of Arts, Slovak Republic
}

\begin{abstract}
Liberalism According to Štefan Launer, or on an Ethno-Emancipation Theory. (This paper has been prepared under the VEGA project No. 1/1116/12). Liberally-oriented Štefan Launer intervened in the complicated Slovak nationalidentification process of the 1840s, who defined himself in relation to the Štúr's group by his radical rejection of their language reform. He considered that reform a gross distortion of the State (Historic-Hungarian) and national (Czechoslovak) integration. Launer made use of the difficult situation of looking for the most suitable solution of language issues of Slovaks in Historic Hungary to expose his own expertise, his intellectual gifts, and his conflicting nature. He developed his own ethno-emancipation theory, through which he not only wanted to attract the representatives of the Lutheran Church in Historic Hungary, but mainly the historic Hungarian political suzerain. The essence of his concept was that he defined the streamlining of cultural and political modernity in Europe from its western part to its eastern part, while having "entrusted" the global history-forming initiative to four of the Western European nations (the Italian, the French, the English, and the German ones), which by virtue of their scholarship and spirit were to revive the Slavic world. Through the above concept, he intended to contribute to resolving the ethno-cultural processes ongoing within the context of modernizing multilingual Historic Hungary.
\end{abstract}

Key words: liberalism, ethno-emancipation theory, Štefan Launer, Slavs (Slavonery), Kossuthan platform of a single Historic-Hungarian nation and the single Historic-Hungarian language.

\begin{abstract}
Liberalizmus v podaní Štefana Launera, alebo o jednej etnicko-emancipačnej teórii. (Táto štúdia je výsledkom riešenia projektu VEGA č. 1/1116/12). Do komplikovaného slovenského národno-identifikačného procesu zasiahol $v 40$ rokoch 19. storočia aj liberálne orientovaný Štefan Launer, ktorý sa vymedzil vo vzt'ahu k štúrovcom radikálnym odmietnutím ich jazykovej reformy. Uvedenú reformu považoval za hrubé narušenie štátnej (uhorskej) a národnej (československej) integrácie. Launer využil komplikovanú situáciu hladania najvhodnejšieho riešenia jazykovej otázky Slovákov $v$ Uhorsku na to, aby zviditel'nil svoju učenost', svoje intelektuálne danosti i svoju konfliktnú povahu. Vypracoval vlastnú etnicko-emancipačnú teóriu, ktorou chcel zaujat' nielen predstavitel'ov evanjelickej cirkvi v Uhorsku, ale najmä uhorskú politickú vrchnost'. Podstata jeho koncepcie spočívala $v$ tom, že nastavil smerovanie kultúrnopolitickej modernity v Európe Launer od jej západnej časti na jej východnú čast', pričom svetodejinnú iniciatívu „zveril“ štyrom západoeurópskym národom (Talianom, Francúzom, Angličanom, Nemcom), ktoré svojou vzdelanost'ou
\end{abstract}

1 Address: Prof. PhDr. Marcela Gbúrová, CSc., Department of Political Science, Faculty of Arts UPJŠ in Košice, Petzvalova 4, 04001 Košice, Slovak Republic. E-mail: marcela.gburova@upjs.sk

Slovak Journal of Political Sciences, Volume 14, 2014, No. 2

DOI: 10.2478/sjps-2014-0006 
a duchom majú obrodit' slovanský svet. Touto koncepciou chcel prispiet' k riešeniu
etnicko-kultúrneho procesu prebiehajúceho v rámci modernizácie mnohorečového Uhorska.

Kl'účové slová: liberalizmus, etnicko-emancipačná teória, Štefan Launer, slovanstvo, kossuthovskej platforme jednotného uhorského národa a jednotnej uhorskej reči

As early as during his study at Lyceums (in Banská Štiavnica and Bratislava) and university studies (Halle), Stefan Launer (1821 - 1851), a native of Krupina, revealed a lot not only as to his philosophical model figures (Hegel, Luther), but also his nature, which predestined him for the role of a future uncompromising opponent of the ethno-political agenda of the Šturan nationforming elite of the $1840 \mathrm{~s}$. Several testimonies of his schoolmates show ${ }^{2}$ that the young student Launer had something of a Napoleonic complex: short stature, vigorous, hardy, boastful, ambitious, obstinate, argumentative, bossy, choleric, "eternal dissenter", intrinsically structured for playing the role of leader of a minority radical opinion stream. In the year 1842, when two rival wings were created among the students at the Lyceum of Bratislava, the majority Slovak one and the minority anti-Štúran one, Launer gave pass to his leadership trait and programmatically sided with the opposition against Śturr ${ }^{3}$. While in Halle, he went into quarrels with almost all the Slovak students there; he only tolerated those who were of undecided opinion, mentally immature, in whom he felt that they needed strong leadership superimposed by a protective hand. In that German environment, he managed to establish alliance with Andrej Lanštják (1821 - 1908), who took sides in his great anti-Štúran mission at the end of the 1840s.

The study in Halle meant for Launer an opportunity to deepen his understanding of Hegel's philosophy of modern Idealism, which enjoyed considerable attention among Slavic students. From Kalinčiak's memories of Sládkovič ${ }^{4}$ we learn that Launer in Halle intensively studied "Hegelianism" and was prepared to professionally discuss this issue only with those who underwent an in-depth study of Hegel's dialectics.

After returning from Halle in the autumn of 1847, he became professor at his former school - the Lyceum in Banská Štiavnica. In that very year he launched

\footnotetext{
${ }^{2}$ See e.g. Rozpomienky na Ondreja Sládkoviča od Janka Kalinčiaka (Sokol I, 1862, pp. 442-445), Grossmann, L.: Nákres života Andreja Braxatoris-Sládkoviča (Orol V, 1874).

${ }^{3}$ Cf. Kleinschnitzová, F.: Sládkovič a jeho doba. Praha 1928, p. 74.

4 "Launer had a quarrel with me within a few days of his arrival saying how dare I (Sládkovič, M.G.) argue with him about Hegelianism when I have not even for a week been breathing in Halle, but that he has been dealing with it for the whole year ". Quoted under Klenschnitzová, F.: Ibid., p. 291.
} 
the implementation of his ideas on the ethno-emancipation modernism in Central Europe, particularly in Historic Hungary and the Slavic world. Launer had systematically been developing the ideas described while still having been staying in the German environment. He arrived in Slovakia with a comprehensive concept which he implemented in three stages. In the first stage, he constructed the philosophical foundations of his vision of the ethnoemancipation modernism, in the second stage he created on those foundations his own variant of the ethno- emancipation theory, and in the third stage he attempted to try out the implementation possibilities for his theory. The accurate understanding of that Launer's ethno-emancipation initiative of the 1840s may be found in his works published between the years 1847 and 1949: Slovo k národu svému (A Word to My Nation, Banská Štiavnica, 1947), Povaha Slovanstva (The Nature of Slavonry, Leipzig, 1847), Všelicos pro obveseleni mysli (All Sorts of Things to Amuse the Mind, Banská Štiavnica, 1848), A Štúr féle tótság veszedelmes iránya (Buda, 1848), Našim milým Slovákům (To Our Beloved Slovaks, Banská Štiavnica, 1848), Vysvětleni proč náš král svržen jest z trưnu? (An Explanation of Why Our King Has Been Dethroned?, Banská Bystrica, 1849).

\section{Stage I}

We have already suggested that Štefan Launer was systematically engaged in the study of Hegel's philosophy while staying in the Halle university environment. Based on Launer's most famous work, Povaha Slovanstva (the Nature of Slavonry), one may conclude that the range of his philosophical sources of inspiration was wider. He explicitly referred to the line of philosophical views (Socrates, Aristotle, Schiller), which presented a detailed insight into spirituality outside of a cognitively recognizable world, thus the absolute spirit which is synonymous with God. In this sense, the finding of $J$. Marták is surprising, who in an effort to prove non-authenticity and speculative character of Launer's philosophical position concerning the issue of spirit and spirituality, attributes to him other inspirational resources (theological writings of Schelling, Schleirmacher, Marheineck, Bretscheider, and other theological philosophers, as well as the philosophical thought of Fichte and Schelling and a group of Hegel's successors, who denied that the spirit [God] is to be found outside the world cognitively recognizable by humans, thus being merely a product of man's imagination) ${ }^{5}$ that substantially left him unaffected in his theistic conception of perceiving the world. These had significance only in the

\footnotetext{
${ }^{5}$ Cf. for details Marták, J.: Útok na spisovnú slovenčinu roku 1847/48 a jeho ciel'. Matica slovenská: Martin 1938, p. 107.
} 
sense that he began to think more freely in respect of certain religious dogmas, in a more liberal way, i.e. in a more open-minded way.

In the issue of spirituality, his position was clearly theistic ${ }^{6}$, which was consistent with Štúr's opinion. They also agreed on the opinion on the essence of religion as "revealed" religion. In this sense, Š. Launer programmatically did not want to deviate from Štúr in his views on the Christian doctrine, realizing the importance of this teaching for the spiritual and moral development of the Slovak ethnicity. In emphasizing the "global historical" role of Christianity as the "God of mankind", he went as far in his attitude as criticizing the destructive role of contemporaneous German atheism in spreading the Christian dogmas. He questioned two of the essential atheistic arguments: "man created God out of himself", "God is just an ordinary man." The fact that Launer distanced himself from the atheistic stance on the relationship between God and man does not mean, as we have already indicated, that in the appreciation of the interpretation of Christian teaching he advocated a conservative attitude. Based on Hurban's criticism of the publication by V. Šimko Egyházi unio (Buda 1842), which promoted a connection of Lutherans with Calvinists in Historic Hungary, one may conclude that Launer in his thinking on the issues of religious dogmas held rather a more liberal position, the one similar to V. Šimko's. The evidence of this may be Launer's stance on the issue of original sin, which is consistent with the Augustinian theological

\footnotetext{
${ }^{6}$ Launer in his book Povaha Slovanstva (Leipzig, 1847, pp. 27-28) mentions on the "Schilleran"'reflections on Christianity and religion the attitude to the concept of spirit that corresponds to Štúran attitude. Ján Marták could have been mistaken by that Launer emphasized the pantheistic principle at the first developmental stage of religion (pagan forms of religion), in which the spirit (God) was the subject of human imagination, being able through fantasy and imagination of man change the substance in different subjects, natural phenomena, and nature itself: "The power developed in the mankind preached to search man everywhere in all cases as an eternal basis for thoughts, and recently made mankind capable of the acceptance of that religion which preaches: God is Spirit: and they that worship Him, in spirit and truth shall pray. Here man no longer seeks God only in the outward form of a tree, animals, stars, etc., but is looking for God in laws eternal unchangeable, which materialize in the nature and spirit of ours, or: that God through nature and spirit of our place implements .... But Christianity has still another goal of man seeking God in himself. But not as the Greeks did, only in the outward form of man in and the beauty of his body, but to know God in his spirit, in this work of God, holy and immortal, that in the inner self dwells. In the spirit of man God left the imprints of His fully ripen properties; just take a deep look into your spirit, know thy spirit, there you can be find the holy parable of the face of God, there you will find all this in a small, what God is in the majesty of His glory and dignity"

${ }^{7}$ Ibid., pp. 28-30.
} 
rationalism popular in Germany at that time. This is demonstrable by the following quote from his book The Nature of Slavonry: "Behold! Here we have the spirit of Christianity, we do see here that it depends on the eternal truth contained in the Christian dogmas; then that it is depends on the eternal will contained in Christian morals, or the Dogma as a type of divine life made possible by the realization of our life; lastly that it depends on the freedom in eternal peace with God's and human law. "8 Separation of the law of God from human laws was emphasized by Launer in particular in his contemplations on the original sin, which are similar to the attitudes of the German rationalistic theologian, K. G. Bretschneider, also known in Slovakia from the circuit of the Levoča Unity of the Youth of Slovakia, particularly from the a dispute between J. Lacko and J. Francisci ${ }^{9}$. Launer questioned the conservative position on the Church dogma of the original sin arguing that if the existence of this dogma had been true, then God himself would have sinned, since he created us. In his expressively formulated considerations ${ }^{10}$ he called the awareness of the original sin a "ghost", which diverts man "from his daily work." He made reference to anyone who believed in that Christian dogma that he would become "such a religious worthless, who by "praying his Lord's Prayer" would at times "drive other people out of their patience". In conclusion he in a mentor-like way warned the potential readers of his extensive book to beware mainly those sins which he was aware of, or which he has the understanding of: "never bother about anybody else, they have long ago been pardoned for you by God, nobody will punish you for such sins." He specifically issued a message to Christians to beware mainly two types of sin: those related to violations of moral standards and character integrity of man and those associated with politics. This type of denial of the original sin and drawing attention to the two types of sins was not random. By making the said thought, Launer indirectly conveyed its positive stance on the direction of Historic Hungarian policy of those years and the Hungarian constitutional system. At the same time he pointed out - within the

\footnotetext{
${ }^{8}$ The above example was also used by J. Marták (Op. cit. in note 5, pp. 105-107), which cited the part cited by us of Launer's book Povaha Slovanstva of pp. 30-31. Marták points out in his book at the same time that Launer saw in the German theological rationalism the top of philosophy and spiritual development at all. True, this view should only be taken conditionally, because Marták does not offer any relevant evidence of Launer's attitude to German theological rationalism.

${ }^{9}$ The essence of the dispute was, on the one hand, the promotion of learning of that German theologian among students in Levoča by the Unity Administrator J. Lacko, and on the other hand sharp objections to this doctrine by the chief administrator of the Unity, J. Francisci. Francisci's letters among the manuscripts of Levočská Jednota Unity No. 64 and 65 in LAMS Martin.

${ }^{10}$ Launer, S.: Op. cit. in note 6, pp. 13-15.
} 
meaning of liberal principles of the Kossuthan-Slovak readers of his book - the political impact of violations of this establishment and the legal system. His demonstrated his perception of liberalism in the reflections of the will of man Christian. ${ }^{11}$ According to him, man due to his will "spills over eternal truth of the Christian sense" into one's life, through his own life, i.e. through his own acts in his own social status, and implementing in civic professions in a way as to be able to say "I" and "truth" are a single unit. Launer, who mastered the mindset of the German rationalist theologians, did not want to "move" the social status or, respectively, with the civic vocation of man claiming that in that "he found revelation of his Humanity": know that "your mind set you for this or any other position, and that is your eternal destination; but knowing that your will as a Christian, i.e. Will eternal, requests from you that you may pursue your priesthood, and again perform your craft persistently, unchangeable, eternally pursued, and thus prove what your mind in itself contains, and prove by the noble deed so that you may say: me and my office are one".

In a similar vein, Launer also contemplated the armorial concept of political liberalism - freedom. He bound the content of this concept to a law which he differentiates into the divine and the human. He reminds in a significantly unsystematic terms, only in terms of his ethno-development theory (more detail on this issue in the forthcoming part of this paper): "When a man implements his life only what universal human and God's will calls him to make, when he imprints as if on a white plate board whatever his age acknowledges as general and eternal truth ... this is Christian freedom. Without the law any freedom is unthinkable." Freedom is therefore "bounded" to a legal framework. Launer argued that the quality of law is directly proportional to the quality of national spirit, or to the degree of national education: "the more enlightened the mind... the more human are his laws". If such laws arise from the will of the nation, then they express the truth and the will of the nation and represent the foundation of its free life. It is only this way which ensures that the laws are legal and legitimate simultaneously. However, the problem with Launer's otherwise correct thinking of one of the fundamental problems of democracy is that he sees the nation in a very conditional way (more on this in the interpretation to follow), whereby he makes his liberal thinking about the relationship between freedom and law significantly problematic.

Launer was inspired by the Hegelian dialectics in both of its aspects: a) any thinking is dialectical, b) in all the world processes, there operates a dialectical process and development, extending from the "undifferentiated" beginnings toward becoming more certain at the end. The spirit in its three forms

${ }^{11}$ Launer, Š.: Op. cit. in note 6, pp. 13-15. 
(subjective, objective, and absolute) is the dominant "actor" not only in the developmental trajectory of man, but in the entire history of humankind. Any progress in self- implementation of individual, any change in the evolution of human history, are manifestations of the Absolute Spirit. He also took interest in Hegel's theory of the State as the supreme expression of human freedom, as a result of continuing developments in the family and the civil society. Like Kollár and Štúr, Launer too reproduced in its ethno-developmental theory some of the thoughts of the impressive philosophy of history by J. G. Herder.

\section{Stage II}

As mentioned above, Štefan Launer undertook the conceptual equipment and the concept of the spirit, which has become known as philosophical term mainly due to Hegel. Under the prism of that spirit in its three forms, Launer interpreted human history, and within it the function of each of the "worldhistorical" nations that have each taken over their respective leadership roles of the human community in their historical development. In that perception of the ethno-developmental trajectory of human society in the European area, which foresaw the formation of a higher ethno-emancipation synthesis, he paradoxically - occurred out of the theoretical frameworks of the concepts J. Kollár and L. Štúr, although all of them were inspired by the same philosophical thinking - from Herder through Hegel up to his successors. All three of them came out of "the spirit of the Western European age“. Kollár and Stúr, however, found that the Slavs would, according to this philosophy of culture, find themselves in an inferior position compared to the "worldhistorical" Western European nations. This would have been even so more dangerous for small Slavic nations that it would have been almost doomed to spiritual assimilation with the culture of the larger neighboring nations. Therefore both Kollár and Štúr, having drawn on Hegel's dialectics, which required a large ethno-cultural diversity for naturally forming a higher ethnocivilizational synthesis, concluded that the Slavic peoples (tribes), provided they wish to rely on the strength of their spirit, had to not only protect themselves against the aggressive non-Slavic cultural influences, but also needed to develop their own spiritual identity and replace the power weakness by the awareness of cooperation and solidarity of the entire Slavic world.

Out of the above knowledge, Ján Kollár elaborated the idea of Slavic reciprocity. It is based on the concept of a single four-tribe Slavic nation with a high cultural and civilizational mission and a common Slavic language. $\mathrm{He}$ divided that nation according to the tribes into Russian, Polish, Illyrian and Czechoslovak "dialects" with the relevant "sub-dialects". Kollár's concept, based on the German idealistic philosophy of history and culture, became a sort of Slavic "Gospel" especially for the younger generation of Slavic nation- 
forming elites, which it inspired for the national activities and knowledge of the Slavic culture as a whole. Stúr followed Kollár, but with the difference that the former did not want to limit Slavic literary languages to four of them. He recognized the right of individual development to eleven Slavic languages, Slovak included, which he placed amidst of them, relying on the romantic theory of Tatra centrism (the Tatras - a homeland of the Slavs). Štur believed that each Slavic tribe had the right and duty to educate themselves in their native language. He associated the issue of the national language with the idea of moral and cultural developing the national community with its political activities and ambitions. He believed that the Slovaks would succeed within the Slavic world as its separate tribe through their language, while cultivating the Slovak spirit in its various manifestations they would fully engage in a major cultural and civilizational role that the Slavs were to fulfill in the history of mankind. At the same time, he wanted to create a natural barrier to the influences of large national communities, including the German national spirit, not to mention the avoidance of assimilation efforts by the Hungarian political power circles after the year 1840, when by passing the language laws (Act VI of 1840 and Act II of 1844), the Hungarian language acquired the exclusive status of the official and working language throughout the country and in public administration authorities, but also in ecclesial life and education of Historic Hungary. Kollár's disagreement with Štúr's conception of language and tribal independence the Slovaks share is more or less of developmental and generational nature. At the time of thinking about Slavic mutuality, Kollár was taking into account the Slavs as a whole, he was not yet looking for their spiritual strength in the quality of their diverse ethno-cultural manifestations, these were rather contained in their large ethno-tribal communities. He therefore considered the Czechoslovak cultural unit of power-political, cultural and civilizational aspects as more meaningful than crumbling it into two separate tribes, which in confrontations with strong neighbouring cultures and power-policy manifestations might have lost a lot of the authenticity of their national identity.

In his ethno-civilizational theory, Štefan Launer took a different path than Ján Kollár and L'udovít Štúr. According to him, the "chosen" nation, which is "the revelation of God of its age", or which partially implements God's idea and comes from a part of the world different than Slavic. Such a nation has the right of history, its acts are recorded in the "book of the world history", in it and through it the eternal scenes of the world spirit manifest themselves, it teaches and manages other nations, its spirit determines the forms and rules for the rest of the community. According to Launer, the Greeks were the first such "world-historical" nation; they are the creators and founders of the human spirit and its education. Other nations grew out of their spiritual strength. In this 
context he introduces the concept of "little nation(s) (národok/národky)“. He means smaller ethnic communities, such as the Slovak ethnic group that in the past had only served as "tools" of higher objectives of the "world-historical" nations. By the termination of the historic mission of such a nation, their value as "instrument" terminated as well, or their continued existence lied only in the fact that they spiritually "languished" on the stage of human history.

Launer's basic theoretical thesis is as follows: Europe in the first half of the early $19^{\text {th }}$ century was no longer represented, as it had been the case in ancient times, by just one nation (Greek, Persian, Roman), rather there were four "world-historical" ones: the Italians, the French, the English, and the Germans. They were the spiritual "pillars" of that age, its supreme rule, the highest standard and superior authority. All of these nations were the epitome of one and the same Christian spirit. Fruits of the spiritual culture appear in the literature of those nations. Other nations of Europe, big or small, are mere spiritual "tags" of those nations.

Launer's "impressionistic" interpretation of the "world-historical" role of those nations - "parts" of a single Christian spiritual group - is as follows:

Italians represent the first stage of the European education and enlightenment. They introduced the Christian spirit in their poetic images in the imagination. They represent the Catholic form of the Christian Church which "sees" the Christian truth in poetic images "hears" it in music and the singing, "smells" it in the incense, and the like. Launer exemplifies its evocative reasoning by the examples of the Italian literature, painting, sculpture. Italian science, according to him, is more concerned with natural issues than with philosophy. In this respect one may consider a bit strange to read his insights on that the Italians are one big "Christian poem", are the mother to "European-Christian" education, and that their philosophical reflections usually begin and end on frogs, cancers, fish, and the like. Of similar information value is another of his observations that when Western Europe thoroughly "looked" at the Italian ideal Christian world, it found that it did not suit it, since what was at stake there was just "alluring and illusion of a sense, just an empty idol", while on the basis of that knowledge there arose in Western Europe germs of the Reformation. ${ }^{12}$

Reformation did become for Launer the highest degree, where the spirit of Europe in the 1840s manifested itself. He assesses the French from the view of the Reformation. He recognizes in them the second level of European education. In France, Catholicism is predominant, like in the whole of Europe. Yet, he advocates the thesis that "the spirit as well as strength, and especially that power, which indicates both measures and tones to our whole age, which delineated the lines and rules of education, is standing on the side of

${ }^{12}$ Ibid., pp. 35-41. 
Protestantism."13 From the above argument he concludes a problematic observation that the French legislation and the government reform, which due to the French Revolution spread throughout Europe, has had its philosophical and historical origins in Luther's Reformation. It is another thing that Luther had released the shackles of medieval Catholic mysticism and freedom of thought and liberated "soul" of the laity from the priestly conservative aristocracy. What Launer properly noticed was the fact that the French had given Europe the State, that they answered the question what the political freedom was and declared human equality in the spirit of Christianity: get the aristocracy (monarch, king, ruler, squire) rid of their privileges. He argued about Napoleon, to whom he devoted considerable space in the text, that he had been the "fruit" of the French tree, was not only a "destroyer", but also the builder of the new European legislation, which enabled the construction of the foundations of civic life and the rule of law. He therefore offered to Europe, to get dressed reasonably well according to the internal, renewed, Protestant man, adequate to the nature of his internal nature and rank; ... once the spirit is liberated internally from medieval prejudices and links, that ... this spirit in its innerness, being the law, to freedom came; ... that what the eternal spirit of God's power inspires the movement in the spirit of mankind ... that the eternal movement is given the human privilege of free passage in life and freedom in the world of mess". ${ }^{14}$ As regards the French Revolution, he emphasizes that it resulted in the formation of the foundations of civil-law State with the principles of freedom, equality, and the rule of law. He reminded a fact wellknown in the democratic milieu that the freedom of the individual and the nation may only be achieved where the law applies, where an individual will and the will of a national community materialize. He adds that wherever there is "good and fair law", there "rules" man - fair, free, and "celebrated." This is also an "understanding of Christian liberty in which man at that time only is free, when he obeys his eternal freedom, when man respects just by what lies in him as the eternal, and not according to his arbitrary will, when man is not honoured because his Father was venerable, or because his Father was a yeoman, but because he himself by observing the law became noble and laird." ${ }^{15}$

According to Launer, the third stage of the European education and edification is represented by Englishmen. In view of his dominant theme religion - the Englishmen are evenly divided between Protestants and Catholics. He supports this information by his finding that the Church in England was reformed, but the administration there remained almost entirely

\footnotetext{
${ }^{13}$ Ibid., p. 41.

${ }^{14}$ Ibid., pp. 46-47.

${ }^{15}$ Ibid., p. 51.
} 
Catholic. In this context, another of his claims is noteworthy that the difference between Protestantism and Catholicism in all of the "southern" European nations is characterized by the fact that "... the more of Romance and Germanic peoples' life blood is mixed in, the more of Protestantism perspires through them. ${ }^{\text {" }}{ }^{16} \mathrm{He}$ supports that difference by a short philological reasoning, stating: the more is the speech of Romance nations "Latinized, i. e. closer to the Latin language", the greater the predominance of Catholicism. And since the Italian language stands closest to Latin, Catholicism is therefore the strongest in Italy. From the linguistic point of view, Launer's account of French and English is "remarkable": "...Latin chewed-up in the German mouth transformed into French... the English speech is despicable, and quite bulky a mechanical mix of German and Latin, and partly an amount of the old Brittons' speech mixed together, so it does not even have legs, and even by word it is a true bat of the old world and the new world." 17 When making the typology of the French and the English, he emphasizes the French Reformism in the domain of democratization of political and public life, and the English Reformism in the field of shipping, "shop-keeping", and technological progress in the field of industry (he particularly highlights "steam engines" as "the flower of the English spirit and the most celebrated work").

Finally, the Germans appear to take the highest ranking in Launer's valuesystem on the ladder of European civilization and spirituality of that age. This "world-historical" nation is for him the European "sage" and the worldhistorical theoretician", which is destined to give answers as to what is true. Naturally, he associated the Germans with Protestantism as the "worldhistorical" principle. He characterizes Protestantism as a protest against "the Authority of the old world", whereas what he means under that "Authority" is, firstly, the Catholic Church, the Greek and Roman classics, and the Greek philosophy. The greatest man from among all the Germans is Martin Luther, as he defined the determination and the role of the Germans in the human world. He proved by his life, Launer argues, that man can only be saved by his faith without works, because works do not help man to arrive at truth, freedom, and satisfaction. Similarly, Luther did not consider the will and the act a substantial quality of man. He most honoured about him the idea which he connected with the inner freedom. This can be attained by man especially when being oppressed from the outside. Launer concludes from the above that Germany attained its inner freedom, however, at the expense of the outside political freedom. He also highlighted another important Luther's thought: the only true world is the "invisible" Church", the visible "Church" is imperfect. The

\footnotetext{
${ }^{16}$ Ibid., p. 52.

${ }^{17}$ Ibid., p. 53.
} 
German mentality, he says, is "phlegm"(Phlegma), which means that the Germans have prerequisites and skills for theoretical reflection. From this Launer concludes that they cannot excel in the fields that deal with external reality (painting, carving, and others), but they do have prerequisites to develop branches which require immersion in "the depths of the spirit." He says about literature in the context of the German nation that it arises in those nations that have "stories" and in which great spiritual creativity governs. Only this literature may then be described as "objectified, materialized religion". The dominant feature of the national literature is its educational function, as referred by him. It follows that literature has to "raise up a strong desire for a more perfect life ${ }^{, 18}$.

Launer used this motif to sharply criticize the Šturran literature, in which he challenged the myth of the Slavic centre - Tatra centrism and Slav centrism. $\mathrm{He}$ condemned the said myth as unacceptable romantic mythological sacralization of the central symbolic object, the Tatras, as a primitive theory of the centrality of the Slavs. He commented in a very unflattering way on the Slovak literature represented by the Štur generation to the effect that "... it governs over the surface of nature, what is missing are just the red Indians' invocations of the holly hills and pseudo Brahmin exclamations: Holy Tatra! Holy Tatra! would echo - where a nation and its putative representatives quite forgot its life-giving content, and instead of religion, education, and rights, as well as its eternal life and eternal salvation, they had given this nation a kind of strange voice: Tatra - Tatra - Tatra - they call, that this disgusting repetition of the Tatras must become repugnant to the nation..."19. At another place of his book, he develops this anti-centrist theme in the sense that he takes away from the Tatras any higher spiritual symbolism (a modern myth of the national-type idea, the idea of a tangible centre as the seat of the spirit, the mind centre, the language centre, the sacred element of the centre, the place of preserving the original values, a "cosmic" mountain range - a connecting line between the heaven and the earth, etc.), just the contrary, the Slovak high mountains are an epitome for him of a low natural substance: "Tatra has not only wood and rocks and underground smell in its caves, this spirit is not for the Kingdom of God. ${ }^{\prime 20}$ Instead of Slavic he centre, Launer outlines the Christian (spiritual) centre, which is God: the Slovak has "as the lofty throne of his not any Tatra, but God." ${ }^{21}$

In relation to the characteristics of the German nation, he quite naturally touched on the nature and content of philosophy. According to him, philosophy

\footnotetext{
${ }^{18}$ Ibid., p. 69.

${ }^{19}$ Ibid.

${ }^{20}$ Ibid., p. 141.

${ }^{21}$ Ibid., p. 161.
} 
explains how far mankind has progressed in its search for and examining of the things of God, the self, and the nature. Philosophers, who may also be found among the German people, are just "interpreters of the spirit of their age." In this context he quotes Fichte well-known statements about the nature of philosophy ("Die Philosophie ist das Wissen des Wissens"), to which he responds by an attempt at his own definition of philosophy: "Philosophia is pure awareness of the principle that was the essence of a whole age, and about which that whole age was turning." "22 This is especially true for the Germans, whom he calls "the Theorie of the current educated world", because "they are those registrars of events and actions of the spirit world... they show that general measure to the world, as long as humanity in the knowledge of God, self and nature has penetrated,... they are the philosophers our age”, they are "the interpreters of the spirit of the world", they utter those principles around which "a certain age was actually spunning."

Following this part of his interpretation of the ethno-emancipation theory, which is a construction of real facts and fictitious ideas, Launer implemented its second part. It was foreseeable that he will focus on the Slavic world, its "fundamentum divisionis". He raised the following two questions: 1) Into how many significant parts are the Slavs divided, and why? 2) How many significant literatures correspond to this division, and why?, which questions he attempted to answer in a way similar to the first part.

The answer to the first question arose quite logically from the first part of Launer's theory, in which he introduced four profiles of the "world-historical" nations. To these four Western European nations, he had in his metaphysical structure to devise adequate four recipients of their spirituality and education of the Slavic world. He thus divided the Slavs into four parts for the following reason: how the Italian, the French, the English, and the German "characters" are reflected in the foundations of the Slavic ethno-emancipation process. Launer determines to the aforementioned four Western European nations the role of "troughs, through which the main origin, $i$. e. the mankind, flows into the Slavs, and 'cause there only are four of the troughs, the Slavs are also supposed to divide into four essential sections ",24. At the same time, he tried to prove that into each of the branches of the "four-branch" tree of the western European education, the seeds of life of the Slavic tribes are to be sown in terms of their "world-historical" constitution. Other solutions of the Slav question, it means Kollár's, Šafárik's, and Štúr's, have, according to him, no logical reasoning and philosophical-historical consistency.

\footnotetext{
${ }^{22}$ Ibid., pp. $72-73$.

${ }^{23}$ Ibid., pp. 73-74.

${ }^{24}$ Ibid., p. 80.
} 
His solution is as follows: 1) the Italian scholarship is represented within the Slavs by the Illyrians, i.e. Croats; they must also have their own special literature. 2) the French education and the French spirit among the Slavs are represented by the Poles (and they too must have their special literature). 3) the English "world trading" and "shipping", which is the essence of the English, is represented in the Slavic world by the Russian people, and they too must have their special literature. 4) German edification, the German spirit among the Slavs, is in turn represented by the Czechs, Moravians, Slovaks, and Silesians. This means that they too must have their own specific literature.

This is the concentrated form of the whole Launer's answer to J. Kollár to his thesis of four literary Slavic languages and literatures. It is true that Launer coincides with Kollár on the concept of a single four-tribe Slavic nation and the common Slavic language, broken down by tribes into "dialects", but Kollár's idea of Slavic reciprocity was vastly different from Launer's idea on that, as it presupposed a higher Slavic spiritual synthesis. Launer did not seek what Kollár was seeking, i.e. the spiritual link among the Slavs, he was rather interested in the differentiating characteristics of the Slavic tribal arrangement.

Let us now take a look on how Launer categorizes the groups of Western European "world-historic" Slavic nations and tribes.

He compares Croats to Italians. This comparison shows that they must be Christians - Catholics, in politics they must profess conservative values. It should be recalled here that Launer divides people (nations) according to their religion. Whereas the Catholics are, in his opinion, conservatives in their civil and political life, the Protestants (Lutherans) are liberals. Launer in his "theory of influences" typology goes as far as describing Croats as Slavic Italians: they sing, feel and think the same. Therefore they are not able to show any reciprocity with other Slavic tribes, not even with their southern Slavic neighbours - the Serbs, since these belong, under Launer's confessional key, to the Orthodox Eastern Slavs - the Russians. Since the Orthodox Church does not enjoy any dominant position in any of the western "world-historical" European nations, it could not have even played "its world-historical" role. Serbs are for Launer just a "small nation" (národok), which cannot even have their own literature.

The French branch of Western European education is represented by the Poles as one of the Slavic nations. Here again, in the spirit of his "theory of influences" logic, he gives testimony to the typologically identical pair of nations. In addition to generalizing the physiological properties of both of the nations (of sanguine type), he forgot to incorporate into the Polish milieu Protestantism alongside with Catholicism, which he recognized in the French nation. Thinking about the notion of freedom he proves that the Poles had never had any freedom, as evidenced by the fact that their vocabulary does not 
recognize the concept of freedom, but only the term "volnosć", which means "exuberance, skittishness". However, as he emphasizes, freedom is "indebtedness", specifically by law, which foresees the will to be free within the law, and this is what the Poles lack.

The Russian nation is in Launer's perspective a representative of the English fleet in the Slavonry. Therefore he presents, way of example, the historical merits of the Tsar Peter the Great for the Russian and the world shipbuilding industry, and made sure to mention the "world-historical" role of Western Europe, particularly of England and the Netherlands, in raising high the level of the Russian shipbuilding industry. Russia, according Launer, has not created anything that might intrigue the "world-historical" spirit, which would have lifted it up and strengthen it. Russia at that time was being only being on the receiving side, did not give out anything. In order not be accused of Pan-Slavism or of being Russophile, he presents such an evaluation of the Russian reality, which had been well known and generally accepted as "the results of the West European States". From this perspective, one may characterize his other claims on Russia: Russia is "Substance and Independence" of Slavs with the preconditions for an independent development with the assistance of European education; the future of the Slavic world is concentrated in Russia; Western Slavs are "by spirit and flesh" of Western education, therefore they cannot be part of the Eastern Slavs.

Finally, Launer tried to prove that "the Czechs, Moravians, Silesians, and Slovaks, having German education as the basis and substance of their life, have to have one and indivisible literature." ${ }^{25} \mathrm{He}$ first shows that Historic Hungary is divided into two main parts: one part of it focuses on the practical western European politics (represented by the Hungarians, who, as the makers of the laws of Historic Hungary are oriented towards French and English education and politics), the second part focuses on the German theoretical-philosophical way of life (represented by the Historic-Hungarian Slovaks and Czechs aiming at the German "paper" politics, their morals, science, and religion). In his extensive historical considerations, Launer proves that Czechs and Slovaks were "created" just for the principle of German Protestantism. In short, one may introduce his thesis, which he implements by a hardly correct analysis of historical facts as follows: the German spirit is in its essence one of Protestantism, the Czechs became the followers of this German spirit in their Hussite movement, they exerted their influence on the Slovaks and the entire Historic Hungary; whereas the political form of Protestantism is constitutionalism, the Historic Hungarian constitution was also established by the influence of Hussitism. Out of this account, what could have emerged for

${ }^{25}$ Ibid., p. 120. 
Launer was merely a politically purposeful characteristic of the origin of Slovaks, which was a response to Štúr and "the new Slovaks" in search of their original roots of Slovakness: "You who are looking for the originality of Slovaks, and see the eternal origin of the Slovaks, see and know that the Slovak recognized his origin in Protestantism, as well as his roots of originality, i. e. he had shown long time ago where he had come from and what he was capable of doing: he is capable of Theology and Philosophy, he is capable of doing what the Germans are able to do, and alongside with the Germans also the Czechs, Moravians, and Silesians; he is capable of leading a Church life, he has a religion; he is not capable of political life, not able to pass his own legislation... the Slovak is seeking his satisfaction, and his most blessed dwelling place in an idea, in the realm of spirit, he is theoretician, and should anybody by God know how to force him into politics, he only would just turn back to his worn-out tracks ${ }^{126}$. According Launer, everything of value in Slovakia has come from the spirit of the German people (knowledge of the nature, of himself, of God, of moral life:"... all this has been set up for us Slovaks according to the German spirit and life as our highest standards, as our eternal... and unchangeable law..."27). Not surprisingly, therefore, his fiery appeal to all Slovaks: "Slovaks! If you wish to live and live forever within the Slavs, you have to stay with the spirit of Germanness and bring the German spirit of freedom and scholarship into Slavonry!"28 This appeal was meant as a response to the appeals to protect the baseline values of Slovak ethnicity (traditions, costumes, language, etc.).

A special chapter of his theory of the Czechoslovak tribe is his defense of Czech as a tool of giving expression of the spirit and "being" of the entire nation. Mainly for that reason he did not accept the concept of Štur's national literary language of Slovaks which he called "a work of naïve painter" and saw the whole Štúr movement as aimless. Whereas, according to Launer, the Slovaks lack an authentic Slovak spirit (for him the "original" Slovak is a "very original fool" and "bully" unable to live a "higher, decent, human, free" life); the Slovaks cannot have their own authentic literature, nor their own "special tribe": in Historic Hungary, they are "just a branch of Moravia in the same way the Šariš population are a branch of the Poles and the Ruthenians are a branch of the Russians." ${ }^{29}$ From the text of the book Povaha Slovanstva (The nature of Slavs) it is clear that he could not quite cope with the serious issue of Catholicism in Slovakia, this is why he leaves open, unresolved (he is only being clear in his finding that Bernolák's language - the language of

\footnotetext{
${ }^{26}$ Ibid., pp. 156-157.

${ }^{27}$ Ibid., pp. 164-164.

${ }^{28}$ Ibid., p. 164.

${ }^{29}$ Ibid., p. 195.
} 
Catholics - is at a lower stage of the development compared to Czech, and Šturr's Slovak is at the lowest stage of development, because its very spiritual "father" - Štúr - is not Catholic or Protestant by spirit); not even the new Slovaks fit within his conception, although most of them professed the Protestant religion.

This is the essence of Launer's ethno-emancipation theory, as presented in his major work, Povaha Slovanstva (the Nature of Slavs). Compared with Kollár's and Stúr's concepts, it has brought a new perspective to deal with ethno-development issues in the Slavic world, while having opened a number of issues of contemporaneous geopolitical and political character. We will now try to give answers to some of them.

\section{Stage III}

Launer's theory may be explored from several angles. Given that it arose during a very complicated struggle for rebuilding feudal multi-ethnic Historic Hungary into to a modern statehood, it is important to have a look at the responses of three actors on the contemporaneous cultural and political scene, who had their ideas of modernization and of Launer's ethno-emancipation initiative.

The most affected party immediately responded to Launer's theory - "the new Slovaks" i. e. representatives of Śtúr's romantic wing that shaped the national agenda of the Slovak ethnic group under the new political and social conditions in the 1840s, in which addressing the issue of the language of Slovaks played a decisive role. They were encouraged to do so by the monarch, Ferdinand V, by issuing the so-called Illyrian Resolution (January 1843), in which he stated that one cannot obstruct the natural development of the vernacular in Hungary. Language or monoliguality was regarded by Štúr and his fellows the most important factor of national identity. Štur himself as the creator of the Slovak national ideology correctly recognized that the most common Slovak dialect - the Central Slovak one - can become the basis for resolving the issue of language in Slovakia. Therefore, in that decade he focused on finding an agreement on the future shape of the Slovak literary language and its spelling system. This search resulted in two historic meetings: the first one at the parish office in the village office of Hlboké (1843), where attended by L. Štúr, M. M. Hodža, and J. M. Hurban the final decision was adopted to enact the literary Slovak, and the second meeting in Bratislava (1851), in which the representatives of Šturr and Bernolák agreed on the form of the standard Slovak language and its spelling rules. Understandably, this ethnoemancipation movement in the Slovak milieu had its opponents. Among them were not only J. Kollár, who in the year 1846 spoke strongly against the Štúran standard literary Slovak in the anthology Hlasově o potřebé jednoty spisovného 
jazyka pro Čechy, Moravany a Slováky (The voice on the need for unity of the standard language for the Czechs, Moravians, and Slovaks), but even more so the old Slovaks or Historic-Hungarian Slovaks standing on the platform of Kolláran first Czechoslovak cultural and linguistic unity, later (1848) many of them on Kossuthan platform of a single Hungarian nation and a single Hungarian language. Štefan Launer and Andrej Lanštják also reported to the Kossuthan aristocratic reform movement, which set off in the year 1839 from the political environment proclaiming a great future for the Hungarian nation through moral and cultural supremacy (led by Earl S. Széchenyi). In this context, it is an open question, how both of these authors came to the attention of the Hungarian aristocratic liberals led by L. Kossuth, F. Putszky, and Earl D. Vayo. To answer this question means to identify the political objectives of Kossuthan Liberals. Kossuthan movement was, on the one hand, developing a combat against the Viennese centralism with the purpose of winning for Historic Hungary the widest possible statehood within the monarchy. They proclaim the emancipation of the Hungarian nation, reinforce the hegemony of the ruling nation in Historic Hungary, support the development of the Hungarian language as the main sign of sovereignty of the nation and the main medium for the dissemination of national culture, awareness, and education. The movement also seeks to strengthen the Historic-Hungarian centralism and bring down the national-emancipatory efforts of non-Hungarian ethnicities in Historic Hungary. For the sake of implementing its political goals and promoting its liberal agenda, the movement also needs to win collaborators from among the ethnic communities of Historic Hungary, whose role would be to degrade within these communities any emancipatory efforts of the nationforming elites. It offers various advantages for that activity. After arriving in Banská Štiavnica, Launer instantly identified the Historic-Hungarian political situation. As is clear from his journalistic writings and from his ethnoemancipation theory, he knew how to bring the attention of the actors on the national and the Historic-Hungarian political scene to his political position, which fully corresponded to the new social and economic reforms of the Kossuthan liberal movement. It is pretty difficult to decide today whether this was his attitude of an authentic political conviction or whether it was part of the management of his career as teacher at the Banská Štiavnica Lyceum, or a response to the new Slovaks to their concept of national individuality. In any case, Launer's stance best suited the ideologues of a single-nation Historic Hungary, who in fact made use of it to their political advantages.

The new Slovaks were getting gradually acquainted with Launer and Lanštják, and appropriately responded to his indiscriminate criticism. The year 1847 was particularly abundant in their mutual confrontation. Launer first presented his publication Slovo k národu svému (A Word to My Nation), 
followed by his most famous book, Povaha Slovanstva ( The Nature of Slavs), and finally a brochure written in Hungarian ${ }^{30}$, by which he responded to Štúr's poem greeting the new Historic Hungarian Palatine, arch prince Stephan of November $1847^{31}$. It should be noted that the above poem was a pretext for Launer and also an opportunity to introduce himself to the Hungarian political scene by a condensed "replica" of his "Slavic" theory, his renegadism and his devotion to Kossuthan political orientation, which, as already indicated, was governed by a dominant idea of a single-nation Historic Hungary. Launer responded to this idea very positively. He emphasized in several places of his text that although he was Slovak by nationality, historically, etymologically and spiritually belonging as a "small twig" (csak egy kis ágacskáját) to the Czech-Moravian-Silesian-Slovak nation, politically he felt a citizen of his Historic Hungarian homeland. ${ }^{32}$ The Štúr group were to him rebels and enemies of the homeland who criticized the freedom of language in Historic Hungary. By Launer, teaching in Historic Hungary was in Slovak (i.e. Czech, M.G.). The fact that he supported the efforts of the Historic Hungarian political circles that Hungarian replaced Latin in Historic Hungary as a language of diplomacy should have been welcome by all the Štúr fellows. Andrej Lanštják chose a similar tactics. First he presented an anti-Štúran work written in Slovak under the title Śtúrovčina ${ }^{33}$ (he dedicated it to Launer, suggesting that Launer was his great ideological model) to write an abridged and partly amended version a few months later of his article in Hungarian ${ }^{34}$, which responded in a critical vein to Hodža's work Dobruo slovo Slovákom súcim na slovo (A Good Word to Slovaks Worth a Word, 1847) and to the agenda of the first nationwide Association and the ideational and organizational centre of the national cultural efforts - Tatrín (1844). When the Historic Hungarian Parliament approved constitutional laws on $15^{\text {th }}-18^{\text {th }}$ March 1848 that the monarch Ferdinand V signed on $11^{\text {th }}$ April 1848, Štefan Launer promptly signed up to speak once again by a work written in Czech, Našim milým Slovákuim (To Our Dear Slovaks ${ }^{35}$, which pioneered the March laws under the

\footnotetext{
${ }^{30}$ A stúrféle tótság veszedelmes iránya. Irta Launer István, a selmeczi lyceum zbli, tanára. Budin 1848. Nyomtatott Bagó Márton betüivel. M 8, 16 pp.

${ }^{31}$ Cf. for details Marták, J.: Op. cit. in note 5, pp. 156-157.

${ }^{32}$ Cf. also Rapant, D.: Slovenské povstanie v roku 1848-1849, I/1-2 -V/1-2. Bratislava 1937, 1947, 1948, 1950, 1954, 1956, 1958, 1961, 1963, 1967, 1972, pp. 113-114.

33 Štúrowčina a posauzení Knihy „nárečja Slowenskou“ sepsal a wydal O. H. Lansstják. W Budjně. Literamí Jana Gyuriána a Martina Bagó. 1847. Lanštják takes polemics in the book with the Šturan tribal theory.

${ }^{34}$ Anti-Magyar: Irta Lanstják Andeás. Pesten, nyomtatott Trattner-Károlyinál. Uriutsza 453. M 8. $16 \mathrm{pp}$.

${ }^{35}$ V B. Št'ávnici, tiskem Františka Lorbera 1848. 23 pp.
} 
spell of Kossuthan ideology. Due to the fact that this work was accepted by L. Beniczky (assistant commissioner to Mr. Géczy in Banská Štiavnica, commissioned by the Ministry of the Interior to instruct the Slovaks on how to "correctly" interpret the valid legal order) as the ideological basis for his promotional material ${ }^{36}$ intended to the surrounding counties and cities, it can be assumed that Launer was at that time considered a reliable collaborator by the Hungarian political circles of the post-Kossuthan movement. One more important fact deserves our attention in this context, namely Launer's attempt to issuing in Slovakia a newspaper written in Czech with an anti-Štúran focus and in the "Hungarian spirit", which was promoted in every way possible by the above L. Beniczky, and directly by L. Kossuth. ${ }^{37}$ Launer would have certainly been granted the authorization to issue this magazine, had there not been the revolution of 1848, which swept the project out. The Štúr fellows were very closely watching Launer's and Lanštják's behaviour and considered a defensive strategy against this form of renegadism.

They knew Lanštják was lacking in any personal attitude, which was his great disadvantage in technical communication. He was not a serious competitor for them. Maybe this was the reason why they chose an unconventional defense - persiflage. L. Štúr, K. Braxatoris, O. Hodža, and Š. Jančovič ridiculed him completely ${ }^{38}$ in the most correct way - by a wellthought out and argued defense of the concept of literary Slovak. Its result was the unveiling of Lanštják's low moral qualities, but also his working method, exhibiting obvious signs of stylistic negligence and incorrectness and a low professional competence, confirmed particularly by his artsy work with objective facts of cultural, language, and political nature. This focused collective critical attitude toward Lanštják was considered by the Štúr fellows sufficient for the readers of the magazine Orol Tatranskí to see his character and professional profile. It was quite natural that his next public appearance $-\mathrm{a}$ pamphlet Anti-Magyar of the year 1847 found no response with the Štúr group, although one may assume that it had been written for the sake of thematizing Hodža's postulates of his work Dobruo slovo Slovákom súcim na slovo (A Good Word to Slovaks Worth a Word in the Historic - Hungarian widest possible context and critically appreciating it especially in Hungarian journalism and within the Slovak Evangelical circles.

Launer was a different kind of opponent for the Štúr group. Some of them also knew from personal experience about his wayward nature, of his

\footnotetext{
${ }^{36}$ Cf. for details Rapant, D.: Op. cit. in note 32, pp. 151-162.

${ }^{37}$ Ibid., pp. 120-127 and 140-145.

${ }^{38}$ In the satirical and humorous section of Počta from Sebechleby L. Štúr and others did so (Ondrej Hodža in his article Čo bláznovi po rozume, ked' ho ňemá) in a similar manner elsewhere in the journal Orol tatránski, II, 1847.
} 
indiscriminate ways to succeed at any cost, to be somebody in the environment in which he operated. J. M. Hurban pointed to another of his properties subservience $^{39}$, which could have played a negative role in the power struggle of the Štur group in enforcing national-emancipation priorities in the $1840 \mathrm{~s}$ against the proponents of the Great-Hungarian State-forming idea of fast Magyarization of Historic Hungary. It was known about Hurban that when characterizing persons, he employed ardent words. It can therefore be assumed that his attribute given to Launer was based on information from reliable sources. Since he was well oriented in the political life in Slovakia, but also in Budapest and Vienna, and also must have been informed of his efforts to establish the aforementioned magazine in Slovakia, which aspired at becoming the ideological and language counterweight to Štúr's Slovenskje národňje novini (Slovak national newspaper) with the annex Orol tatránski, but also an ideological counterweight to "Kolláran" Slovenské noviny (Slovak newspaper) written in the official language of Slovaks, in the so-called Old Slavonic (it was pushed through as of the second issue in the year 1850). Not coincidentally, he was named a "traitor" of the nation ${ }^{40}$ by the said newspaper editor and the proponent of the Kolláran idea of the Czechoslovak nation, A. Radlinský, because not only Hurban, but also Launer considered his journalistic and political activities anti-national and renegade. L'. Štúr and editors of the annex to the Slovak national newspapers - Orol tatránski employed a tactically thoughtful stance to Launer's works. They found out that Lanštjak's "brochures" have their "supporter", otherwise the author could not have them published for financial reasons. A similar thing happened when issuing Launer's books, especially in his major work Povaha Slovanstva (The Nature of the Slavs), whose publishing costs were so high that Launer would not have been able to master them financially. Ondrej Hodža, in our opinion, perfectly encapsulated who had an interest in publishing the works of both authors: "... I came to learn that it was a thing from the Pest fireplace which the local famous chefs often prepare for us..." fireplace". It was the Historic Hungarian political movement of L. Kossuth, which Lanštják, but especially Launer often invoked, but it can be said that they considered it a major source of inspiration for their political creed. Launer, who had full ideological control of Lanštják, appreciated about Kossuth's political direction - among other things - the fact that he wanted to create a Hungarian constitutional nation-state independent of Vienna out of the feudal Historic Hungarian one. He confirmed his position explicitly in his political creed, which he presented at several places in his main book Povaha

\footnotetext{
${ }^{39}$ Hurban, J. M.: Slovensko a jeho život literárni. Slovenské pohladi I, 4, 1851, p. 143.

${ }^{40}$ Quoted by Marták, J.: Op. cit. in note 5, p. 46.

${ }^{41}$ Braxatoris, K.: Otvorený list L. Štúrovi. Orol tatránski, II, 1847, p. 510.
} 
Slovanstva (The Character of Slavs). In it he subscribed to those who wanted to expand the numbers of Protestants - Liberals in the Historic Hungarian homeland, who wanted to promote the Historic Hungarian constitution and its laws and the Kossuthan liberally-oriented magazine Hírlap. When Ctibor Zoch read the "announcement", which instructs Slovak readers to subscribe Launer's book The Character of Slavs, he replied very promptly, modeled after the Štúran critical strategy to the work by Lanštják, by a polemically oriented article published in Orol tatránski ${ }^{42}$ before publishing the above book. Zoch realized that by way of his "preventive" criticism he might discourage Slovak readers from making another attempt at destroying the roots of the Śtúran ideology at the time when it needed support and extension of its territorial, social, and cultural basis. At the same time, he realized a negative political impact of its positive presentation in the Slovak milieu. While thinking that Launer be given an opportunity to defense his approach in relation to compliance with the principle of freedom of expression, but ultimately he considered it for better, "to fight when all sorts of those creatures emerge out of the Slovak non-Slovakness, which may be found in any corner and would grow as a bad plant - they will rot, smell, and perish away." ${ }^{43}$ Zoch probably assumed that this would put an end to the Launer "case". But he was wrong. Probably he had no idea that Launer would never forgive such criticism. In December 1847, he issued a "brochure" Slovo k národu mému (A Word to My Nation), in which he wanted to show the "true" face before the Slovak nation of not only K. Zoch, but also of Štúr, his Slovenskje národňje novini and their editors and colleagues. However, he did show his "true" face when instead of presenting the arguments, he resorted to a very "low" method of classifying his opponents. Launer's attack was also directed at Daniel Lichard, which can be explained by the fact that at that time his former professor of mathematics in Banská Štiavnica reported the publication of Novini pre hospodárstvo, remeslo a domáci život (Newspaper for the Economy, Craft, and Home Life) in Štúr's Slovak. Since Lichard felt very touched by this "canal" criticism, he considered it necessary to respond to it quickly in order to purge his name. Štúr, who originally had not intended to pursue any further litigation with Launer on the pages of Orol tatránski, made an exception in case of Lichard. He published his Otvoreni list Pánu Štefanovi Launerovi v Śtjavňici (An Open Letter to Mr. Štefan Launer in Štjavnnica $)^{44}$ in which the readers could make their own picture of the differences between the level of responses to both of the parties "concerned". Moreover, in this case Launer suffered one more - moral defeat: disrespect from his students at the Ecclesiastical Evangelical "School

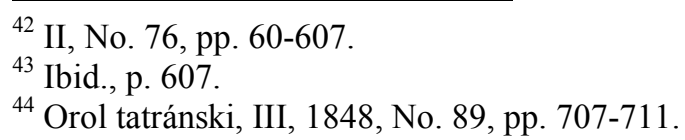


of Education" in Banská Štiavnice (where he was teaching philosophy), from his Church - the Evangelical community, from the proponents of literary Czech and from the wider surroundings of Banská Štiavnica, including the Catholic community of believers whom he considered the supporters of the reactionary conservative national line. D. Lichard essentially ${ }^{45}$ ended the controversy with Launer's views in the Slovak press and we should add that in a way he inspired other columnists (such as those from the camp advertising Czech or Czechoslovak) not to respond to Launer's book titles, including his main work, The Nature of the Slavs. There was one more fact of a political nature, why Launer was so bold in his critical attacks against Štúr. Štúr might have considered taking a legal action against Launer, but he knew pretty well that in any legal dispute he could lose more than gain. He realized two essential things: 1) His negative position with the general superintendent of the Lutheran Churches and a zealous promoter of the Union of Lutherans of Augsburg Confession, Karol Zay, who worked closely with the government of Historic Hungarian political circles and had an impact on the administration of the Historic Hungarian Lutheran Education. 2) He knew that if he had violated the condition which was related to the permission to issue Slovenskje národňje novini (it is written in that permit that the paper may not publish "rancorous" articles, "irritant" personal or nationalist attacks ${ }^{46}$ ), he could have lost the license, and this political and legal" buzz" around Launer was not worth it.

From the Czech side, Albert Pražák ${ }^{47}$, a representative of the Czechoslovakoriented science and J. O. Novotný ${ }^{48}$ responded to Launer's work, especially his book The Nature of the Slavs. Pražák, having been an ardent critic of the Šturan concept of the independent standard Slovak and an advocate of the Czechoslovak tribal and political unity, rehabilitated Launer's theory. He even regarded it as an attempt at a philosophy of Slavic history and contradicting the ideology of the representatives of the Slovak national movement organized around Štúr. He particularly appreciated Launer's "original" evidencing the thesis on the Czech-Moravian-Silesian-Slovak single tribal, religious, and spiritual whole. He was only suspicious about three things: Launer's "crisp" and "uncouth" style of his polemics with the Štúr group, his analysis of the Czech character, which he straightforwardly inferred from the German

\footnotetext{
45 Excluding the short critical editorial response in Orol tatránski (1868, No. 84, pp. 670-671) on Launer's article Slovo k národe svému called Nová babraňina oproti Slovenčiňe. This reaction has been triggered by lots of articles to the editor that came mainly from the mining towns of Banská Štiavnica, Banská Bystrica, Kremnica, Lubietová, Slovenská L'upča.

${ }^{46}$ Details in Hodža, M.: Československý rozkol. Martin 1922, p. 258.

${ }^{47}$ In his work Dějiny spisovné slovenštiny po dobu Štúrovu. Praha 1922.

${ }^{48}$ Novotný, J. O.: Středni Slovensko I. Praha 1937, najmä pp. 279-286.
} 
Reformation principle, and finally about his inconsistency in the criticism of Štúr. The said J. O. Novotný did not bring any new knowledge and information about Launer, he basically just took over Pražák's uncritical assessment of the author of The Nature of the Slavs, including the bibliographic and factual errors.

Although the Hungarian liberal political circles expressed considerable interest in Launer's service in the 1840s, their offer to Launer did not ever grow into any official, publicly presented offer of cooperation. Since in addition to indirect evidence there exists a direct evidence of Launer's cooperation with the Kossuthan liberal opposition in the year 1848, we can assume that Launer's renegadism was politically motivated, but one cannot rule out other causes. The very fact that Launer in the year 1848 joined the side of L. Kossuth, prompted the Hungarian literary historian L. Sziklay to ask a question in his work ${ }^{49}$, how could L. Launer, a student of L. Stúr and a classmate of A. Sládkovič at the Lyceum, have opposed the Slovak nationalemancipation movement. Despite the conscious pursuit of an objective interpretation of Launer's activities, Sziklay failed to sufficiently understand the whole national agenda of the Slovak ethnicity, addressing the language issues among Slovaks, and Launer's role in the ethno-development process. Štefan Launer was termed by him a "typical" example of the spirit of the Danube and the Danubian complex ethnic situation of the 1840s. Addressing the language issues with Slovaks, according to him, was abstained by Bernolák's experiment of unifying the nation around the basis of cultural western Slovak and by Kollár's project of Slavic four-tribe idea, while the Biblical language for the Slovaks had apparently a similar function as Latin had for the Hungarians. He admits mistakes that happened in the Hungarian politics, when the government favoured the proponents of the Biblical language to the promoters of literary Slovak. Inaccurate is also his assessment of the schism between the so-called old Slovaks and the new Slovaks, but also the importance of J. Hollý in regard to the adoption of standard Slovak. He is looking for the reason of Launer's (as well Lichard's and Záborský's) antiŠturan activity in his underdeveloped sense of romantic passion and persistence for the "stiff" rationalism, the ideas of the Enlightenment and liberal ideas. He assessed the controversy between Zoch and Launer as generational strife. He interpreted Launer's basic work The Nature of the Slavs quite objectively. He also noticed the style of his work Všelicos pro obveselí mysli (All Sorts of Things to Amuse the Mind), of which he gave a very critical opinion saying that by its brutality it is unprecedented in the world literature. Sziklay's book

${ }^{49}$ Sziklay, L.: Launer István, egy 1848-évi szlovák röpirat szerzője. Budapest 1948. 60 pp. A book review was written by Milan Pišút under the title Renegát či Európan? Tvorba, issue 7, No. 2, 1949, pp. 29-30. 
was an indirect polemic with Marták's assessment of Launer's activities ${ }^{50}$, which he explains by saying that he built his assessment of his person against his "stiffly nationalist" assessment of Launer: he does not see in him a "Magyarone" or "Magyarizer"; he claims that being a "Historic-Hungarian Slovak" he did now want to allow the political solution to the Slovak issue; he assessed the nation according to whether or not a nation has its own national culture. Slovaks in Launer's assessment had not their own culture, they were part of the Czechoslovak culture. He did not seek any political dimension in the concept of national culture, what was the motive of his decision to join the Kossuthan movement in the year 1848. In terms of ideological struggles, that year was full of paradoxes: not even Launer could have escaped them, who reported to the Czechoslovak unity, but worked with the Kossuthans, while pioneering integrity of Historic Hungary and brotherhood of its nations.

The shift from the ethnic to national awareness-raising that Europe registered at the end of the $18^{\text {th }}$ century in Germany as a result of the Enlightenment and the French Revolution was completed in Slovakia by intellectuals from among the Protestants led by L. Štúr in the mid-1840s. They defined themselves against four factors: 1) the line of Czechoslovak cultural and linguistic unity represented by Kollár's concept of Slavic solidarity and cultural and linguistic tribalism where Czechs and Slovaks were considered a single tribe with a common culture and Czech, or better yet, the slovakised Czech language employed primarily as a literary and liturgical language; 2) the extreme wing of the Czechoslovak ideas that promoted the Kossuthan liberal political project of the Historic-Hungarian political nationality and the Hungarian constitutional single-language nation state (Lanštják, Launer, Seberíny); 3) Language "separatism" of the Bernolák group who, when choosing a particular form of the national literary language departed from the

\footnotetext{
${ }^{50}$ Op. cit. in note 5. Marták's assessment of Launer's personality and his work is the first attempt at an objective view of the attacks on the literary Slovak in the late 1840s. Marták based his interpretation on the defence of standard Slovak against contemporaneous attacks and on the analysis of Czechoslovakist ("Pražákan") line of evaluation of struggles for literary Slovak during that period. That procedure might have been the reason why L. Sziklay called Marták's assessment of Launer's activities and his work "stiffly nationalist". It should be stressed that Marták only dealt with a single "episode" of these struggles, which had not until then been analyzed in detail. This was an action taken against theliterary Slovak in the years 1847/48 represented by A. Lanštják and Š. Launer. Marták was the first to separate in his book the Kolláran line from the Launeran line, which, in our view, he correctly named as the extreme anti-Štúran line. It should also be added that although Marták's analysis of Launer's works in correct in interpretations, some analogies between Launer's journalistic performances and the Historic Hungarian political life do not have enough relevant information value because they are not "covered" by authentic historical documents.
} 
marginal Slovak dialects and was refused by the Evangelical part of the Slovak nation; 4) growing Hungarian nationalism, which stemmed from the so-called reform period of the Hungarian political history (1830 s - 1840 s), specifically from Széchenyi's Great-Hungarian state idea and Kossuthan nationalist argument - identification of the linguistic border with the national border, which can be viewed as a result of the French ideas of nation and state.

Having examined all the implications of this definition, L'. Štúr decided to qualitatively shift Kollár's attitude towards the Slavic "tribalism" and call Slovaks a separate tribe and elevate the spoken language to the standard. Štefan Launer intervened in this complicated nation-identification process in the 1840 s, which together with A. Lanštják defined in relation to the Štúr group radical rejection of their linguistic reform. He considered the reform a gross distortion of State (Historic Hungarian) and national (Czechoslovak) integration. Launer made use of the difficult situation of looking for the most suitable solution of language issues of Slovaks in Historic Hungary to expose his education, his intellectual gifts, and his conflicting nature. He developed his own ethno-emancipation theory, through which he wanted to attract not only the representatives of the Lutheran Church in Historic Hungary, but mainly the Hungarian political suzerain. This concept was intended to contribute to addressing the ethno-cultural processes within the context of modernizing multilingual Historic Hungary. The philosophical basis of Launer's theory was almost the same as in Kolláran or Šturan generation - the German, HerderianHegelian, in Launer enriched by the German theological rationalism. The difference between them was that Launer shifted the direction of cultural and political modernity in Europe from the western part to its eastern part, while he "entrusted" the world-historical initiative to the four Western European nations (Italians, French, English, Germans), which by their education and spirit were to revive the Slavic world. He divided the Slavs, like Kollár, into four tribes, but assigned each of them its "world-historical tutor ". The Czechoslovakian tribe was supposed to grow out of the German spirit and its education. In line with this Launeran logic, they were not a nation, just ethnicity. Their language could not have been Slovak, but Czech, their homeland could only have been Historic Hungary, and the official (diplomatic) language could have been Hungarian. Religious aspect played an important role in his theory. $\mathrm{He}$ preferred Protestant religion to Catholic, while having associated the former with liberalism and progress-oriented liberalism with progressivism in addressing the civilizational issues of the European Community. He associated Catholicism with conservatism and value backwardness. He failed to understand that the problem of liberalism vs. conservatism is primarily axiological; the religious aspect in this context only plays a secondary role. Paradoxically, Launer often reported verbally to liberalism, but his journalistic 
activity suggests the opposite: the liberal political theory, or liberal ideals, the creators of liberalism (Locke, Montesquieu, and others.), and does not write at all of, and avoids his ethno-emancipation theory within liberal issues (natural rights and liberties of the individual; the value of freedom of the citizen; ethnic collectivities; principle of tolerance; the theory of the limited government, legitimacy of political institutions, etc.). If any of these principles (for example, the notion of freedom) he does explain, he is doing so only on the basis of one of the contemporaneous variants of political liberalism. He identified with Kossuthan liberal political agenda, which he drew from the traditions of Western European territorial nationalism. Despite his great personal efforts and support among political circles of the Kossuthan liberal movement, Launer did not fulfill his life's ambition. He was a teacher, but his goals were set higher: they pointed to his image of a great political strategist, leader, and thinker. Until the year 1848, he did not become any of these for both subjective and objective reasons. After the defeat of the revolution in the year 1848, he left Banská Štiavnica and adopted a teacher - cantor position in Sarvaš. Based on his nature, it may be concluded that the defeats he suffered as a critic of Štúr and a supporter of the Kossuthan movement, touched him essentially, but did not break him down. He was an ardent supporter of the Hegelian dialectic. For this reason, he could not have become a devotee of satisfaction with the goals attained. Dissatisfaction was not only his character trait. May we just take a liberty of making here a minor assumption: Launer in his new setting in Sarvaš was preparing a new, perhaps even more distinctive entrance into public life than that of the year 1847. It is a possibility. His premature death in the year 1951 ultimately took away from him everything he associated with the future.

\section{REFERENCES}

Hodža, J. M. : Dobruo slovo Slovákom súcim na slovo. Liptovský Mikuláš 1847.

Hodža, M.: Československý rozkol. Martin 1922.

Hurban, J. M.: Slovensko a jeho život literárni. Slovenské pohl'ady I, 4, 1851.

Kleinschnitzová, F.: Sládkovič a jeho doba. Praha 1928.

Marták, J.: Útok na spisovnú slovenčinu roku 1847/48 a jeho ciel'. Martin 1938.

Novotný, J. O.: Střední Slovensko I. Praha 1937.

Launer, Š.: Povaha Slovanstva. Lipsko 1847.

Launer, Š.: Našim milým Slovákům. Banská Štiavnica 1848.

Pražák, A.: Dějiny spisovné slovenštiny po dobu Štúrovu. Praha 1922.

Rapant, D.: Slovenské povstanie v roku 1848-1849, I/1-2-V/1-2. Bratislava 1937, 1947, 1948, 1950, 1954, 1956, 1958, 1961, 1963, 1967, 1972.

Sziklay, L.: Launer István, egy 1848-évi szlovák röpirat szerzője. Budapest 1948.

Prof. PhDr. Marcela Gbúrová, CSc., focuses in her research on the issues of national and civic identity, inter-ethnic communication, issues of human and 
civil rights, the Slovak political history, and current issues of political life in Slovakia after the year 1990. She publishes in both international and national specialist journals and volumes of papers and in daily newspapers. She is the author or co-author of several monographs on the theory and history of political thought. She founded ventures well-known in the community of political scientists, such as the Prešov Days of Political Science and the Košice Dialogues in Political Science.

Prof. PhDr. Marcela Gbúrová, CSc. Department of Political Science, Faculty of Arts UPJŠ in Košice Petzvalova 4, 04001 Košice, Slovak Republic E-mail: marcela.gburova@upjs.sk 